\title{
The Diversification of Local Tuber Products for The Result of Gluten-Free Bakery Products
}

\author{
Elisa Julianti; , Ridwansyah, Era Yusraini, Terip Karo-Karo \\ Food Science and Technology MajorFaculty of Agriculture, Universitas Sumatera Utara, Medan, \\ Indonesia
}

\begin{abstract}
Bakery products such as bread, cake and cookies that currently exist in the market are generally made of wheat flour. Some individuals would suffer from allergy in consuming the consumption products that contain gluten which is found in wheat flour.The purpose of this activity is to produce bakery products such as bread, cake and cookies that are gluten free by using local tuber ingredients, i.e. cassava and sweet potatoes. The activity was started with processing cassavas, sweet potatotes, orange sweet potatoes to be powder which then was processed to be various types of bakery products. The variants of products that are marketed are as many as 31 types, consisting of 28 types of bakery products such as cakes and cookies, and 3 types of wet cake products. The types of bakery products that were sold was brownies, muffin, sponge cake, cookies and snacks with various variants such as steamed, baked, flavors addition of coffee, chocolate and mocha. The bakery products are gluten-free so that they are safe to be consumed by people who are allergic to gluten. The wet cake products that were marketed were risoles, pastels and doughnuts. However, this type of cake is still wheat flour substitute product as much as $20 \%$. This activity may support the national food security program.
\end{abstract}

Keywords: Bakery Products, Diversification, Gluten-Free, Local Tubers

Abstrak. Produk-produk bakeri seperti roti, cake dan cookies yang beredar di pasaran saat ini umumnya dibuat dari bahan baku terigu. Beberapa individu akan mengalami alergiketika mengonsumsi produk pangan yang mengandung gluten yang terdapatpada terigu.Tujuan dari kegiatan ini adalah memproduksi produk bakeri berupa roti, cake cookies dan kue-kue yang bebas gluten dengan menggunakanbahan baku umbi-umbian lokal yaitu ubi kayu dan ubi jalar. Kegiatan dimulai dari pengolahan ubi kayu dan ubi jalar ungu, dan ubi jalar oranye menjadi tepung yang selanjutnya diolah menjadi berbagai jenis produk bakeri. Varian produk yang dipasarkan sebanyak 31 jenis, terdiri dari 28 jenis produk bakery yaitu cake dan cookies,serta 3 jenis produk kue basah. Jenis produk bakery yang dipasarkan adalah brownies, muffin, sponge cake, cookies dan makanan 
ringan dengan berbagai variasi seperti produk yang dikukus, dibakar, penambahan rasa kopi, coklat, dan mocca. Produk bakeri ini merupakan produk yang bebas gluten sehingga aman dkonsumsi oleh masyarakat yang alergi terhadap gluten. Produk kue basah yangdipasarkan yaitu risoles, pastel dan doughnut, tetapi untuk produk kue basah ini masih merupakan produk substitusi terigu sebesar 20\%. Kegiatan ini dapat mendukung program nasional ketahanan pangan.

Kata Kunci : Bebas Gluten, Diversifikasi, Produk Bakeri,Umbi-umbian lokal Received 20 November 2017 | Revised 2 January 2018 | Accepted 23 February 2018

\section{Introduction}

The use of wheat flour as raw material for food industry such as bread, noodles, cookies and biscuits continue to increase from year to year. Indonesia imports flour more than 7 million tons in 2014 and there is an increase in flour import by 5\% annually [1]. Flour has actually been produced in Indonesia, but the raw material of wheat is still imported due to Indonesia's climate condition that does not allow the high productivity growth of wheat. Data from Central Bureau of Statistics (BPS) recorded flour production in 2016 was 5.841 million tons, and to produce flour with that volume, the industry imported up to 7.769 million tons of raw materials. This increased demand for flour will threaten national food security and sovereignty.

The use of wheat flour as raw material for food products, for some people should also be avoided as the components of gluten which are contained in it. Gluten could cause digestion problem for people who are intolerant to it. The ailment that is resulted from the intolerance of the protein of wheat flour is called celiac which patientsfrom year to year turned out to be increasing in numbers. Although the disease is not that common in Indonesia, but there are other diseases that are also intolerant of protein from flour that is autistic disease. Therefore, the use of flour made from local tubers as the raw materials should be developed. Actually the availability of flour and starch throughout the world is more of those that are made of the materials other than wheat. Indonesia as a tropical country, has a fertile soil and natural products are diverse, especially in the field of agriculture. Tubers are one of the agricultural products of Indonesia which is widely cultivated in Java, especially in East Java and Central Java.

The disadvantage of using non-wheat flour in making bread and cake is that it can not produce elastic dough so that the bread product is not expanded and hard. Gluten consists of glutenin and gliadin, and is complex protein that is found in wheat flour and contributes to the elasticity to the dough. Gluten requires adequate hydration and stirring to obtain crosslinking between glutenin and gliadin, so that the connected proteins are formed and it is capable of capturing the gas within the dough. Some starch and starch products other than wheat generally lack the sequence of terminal $\mathrm{N}$-amino acids and therefore are unable to assist in the process of gas capture in the dough and resulting in less elastic dough [2]. 
Research on the use of flour from tropical crops such as cassava, sweet potato, corn, rice, sorghum and milet in the manufacture of cake, cookies, biscuits and various patisserie products such as risoles and pastels have been done frequently [3]. Cake, cookies, and patisserie are snack products that can be used as a source of energy for children and adults [4]. Improving the quality of cookies through fortified proteins, minerals and vitamins at low prices makes cookies serve as one of functional food [5]. The usage of non-wheat flour such as cassava flour and sweet potato flour is also advantageous as the fiber level is also higher.

The community service activities through science and technology schemes for Innovation and Campus Creativity (IbIKK) are conducted with the aim of exploiting the existing market opportunities for bakery products using gluten-free gluten feedstock for consumers allergic to gluten, as well as for consumers who want to consume dietary fiber. Bakery products made from raw cassava flour and sweet potato flour is a healthy food alternative for consumers who prioritize quality and health.

\section{Methods}

\subsection{Raw Material}

The raw materials of the business unit of allergen-free and low cholesterol bakery are cassava and sweet potato. The additional ingredients are ingredients of cake, cookies and gluten-free and / or eggless pastries.

\subsection{Production}

The bakery business that is established has possessed manufacturing facilities which are kitchen for food processing as wide as $100 \mathrm{~m}^{2}$ and required equipments for the mixing of local-ingredient-based of flour and starch as well as bakery products processing, i.e. dough mixer, baking oven and gas stove.

\subsection{Production Processs}

The production process includes the manufacturing process of flour from the local products such as rice, corn and tubers. Furthermore, the produced flour and starch are processed to be various types of food which are cakes, cookies, and other patisserie products, i.e. risoles, doughnuts and pastels. The production process of the flour from local raw materials and the baking process are simple processes with ready-to-apply technology.

Raw materials for baking cakes, brownies and cookies are cassava flour or sweet potato flour, sugar, margarine, vanilla, baking powder, skim milk, salt, emulsifiers and other additives according to cake, brownie or cookie variants such as chocolate bars (cooking chocolate), dried fruit, choco chips, pineapple jam, cornflakes, almonds and cheese. The process of making 
brownies and cakes in general is to mix the flour and baking powder and stir the two ingredients until they are mixed perfectly. Eggs or egg substitutes (for eggless cake), sugar, salt, skim milk, margarine, vanilla and water are stirred using a high-speed mixer for 6 minutes. The flour mixture and baking powder are added to the egg mixture little by little while being stirred with a low-speed mixer for 3 minutes. The dough is then poured into the cake mold that has been rubbed with margarine/oil, and baked in the pre-heated oven at $180^{\circ} \mathrm{C}$ for 35 minutes.

The baking process of cookies refers to Singh et al.with slight modification as follows: margarine and sugar are mixed until soft cream is formed, then eggs or egg substitute ingredient are added and mixed again for 3 minutes [6]. Flour, baking powder and salt are added to the cream dough and stirred manually with wooden spatula until all ingredients are mixed equally. Dough is molded, poured into the baking pan and baked with an oven at $180^{\circ} \mathrm{C}$ for 20 minutes. The baked cookies are taken out of the oven and chilled to be packed afterwards.

The basic ingredients of patisseries such as doughnuts, risoles and pastels are wheat flour, mocaf flour, cooking oil, and eggs. The additives are sugar, yeast, emulsifies, chocolate bars and chocolate rice for doughnuts, and vegetables as the filling of the pastels and risoles. The baking process of doughnuts is started with the dough making of flour, eggs, yeast and emulsifier using mixer, and then the dough fermentation process for 1 hour, molding and frying, and then covering with toppings of melted chocolate and chocolate rice.

The production process of risoles and pastels are started with the making of the dough, then the wrap (for risoles), or the molding and filling of vegetables for pastels. The wraps of the risoles are then stuffed with vegetables and shaped to be risoles. The pastels and risoles dough that is already filled with vegetables are then fried to be marketed afterwards.

\section{Result and Discussion}

The result of community service activities with science and technology scheme for Innovation and Campus Creativity (IbIKK) is a bakery business unit that sells processed products from local tuber flours namely sweet potato flour, cassava flour, cassava starch (tapioca) in the form of cake, brownies, cookies, and other patissery products. This business unit is located within the University of Sumatra Utara and the main target of marketing are students, lecturers, staffs within the campus and the surrounding communities.

\subsection{Product Type and Legalization}

The main product types produced and marketed are cakes (including cup cakes and muffins), brownies, doughnuts, risoles, and pastels. Other types of products are pie and wet cake products such as lepat bugis and layer cakes. All these products use raw materials of cassava flour or sweet potato flour as a substitute for flour. In doughnut products, risoles and pasta, the use of 
cassava flour as wheat flour substitution is still as much as $20 \%$, but for other products $100 \%$ using cassava flour (mocaf) and sweet potato flour. Currently, 39 product variants are produced, and all of them have obtained marketing authorization from the Medan City Health Office in the form of PIRT Certificate and Halal Certificate issued by the Institute for Assessment of Drug and Food Supervision of Majelis Ulama Indonesia (LPPOM MUI) of North Sumatra The complete product type can be seen on Table 1 and Figure 1.

\subsection{Production Capacity and Selling Price}

The production capacity for cakes, cookies, doughnuts, risoles, pastels and the selling price can be seen on Table 2. It displays the production capacity for cookie products is still low and production increases during festivity days such as Eid and New Year. Nevertheless, the production capacity for brownies and patissery products is good enough, indicating that people are getting familiar with products made from non-wheat flour.

\subsection{Marketing}

The products produced by this IbIKK activity is the development and diversification of old products into new products. The marketing method is marketing directly and indirectly. Direct marketing is done by opening outlets in the showroom located in Building Cikal B USU on Jl. Dr.Mansyur, Medan. This marketing place is very strategic as it is on the side of the highway, as well as its location that is facing the USU sports stadium. Direct marketing is also conducted by receiving orders directly from buyers that is improved by distributing product brochures and leaflets, as well as posting posters and banners in several places. Indirect marketing is done through the use of social media and the internet. The use of electronic media such as the internet is maximized by making the Internet as a source of information and training materials organized by the Gluten Free Bakery Products and Low Cholesterol Prodi ITP FP USU, with certain requirements to be able to download certain information. Promotion is also conducted through social media such as Instagram (@innovasibakery), Twitter (@inovasibakery) and Facebook (InovasiBakery).

\subsection{IbIKK and University Relation}

The university has been willing to allocate counterpart funds for 3 (three) IbIKK activities with the amount of $\mathrm{Rp} \mathrm{40,000,000.-/year} \mathrm{which} \mathrm{is} \mathrm{realized} \mathrm{in} \mathrm{rent} \mathrm{payment,} \mathrm{electricity} \mathrm{installation,}$ wi-fi and the remainder is paid in cash used for the purchase of processing equipment flour and bakery products. The Implementing Team of IbIKK is required to report the balance sheet (income and expenditure) to the Dean of Faculty of Agriculture USU every month. The business unit that is established through IbIKK activities is expected to be able to independent and contribute to Food Science and Technology Program, Faculty of Agriculture USU. 
Table 1. Product variants of gluten-free and allergen-free bakery business unit

\begin{tabular}{|c|c|c|c|}
\hline Product Type & Product Name & $\begin{array}{l}\text { Product } \\
\text { Code }\end{array}$ & $\begin{array}{l}\text { PIRT\& Halal } \\
\text { Certificate No. }\end{array}$ \\
\hline Non Gluten & Sweet Potato Steamed Chocolate Brownies & 000794-01 & PIRT No. \\
\hline \multirow[t]{6}{*}{ Brownies } & Sweet Potato Baked Chocolate Brownies & 000794-02 & 2.06.1275.01.0 \\
\hline & Cassava Steamed Chocolate Brownies & 000794-03 & 202.20 \\
\hline & Cassava Steamed Chocolate Brownies & 000794-04 & \multirow{4}{*}{$\begin{array}{l}\text { Halal No. } \\
092000079408 \\
16\end{array}$} \\
\hline & Cassava Steamed Cheese Brownies & 000794-05 & \\
\hline & Cassava Baked Cheese Brownies & 000794-06 & \\
\hline & Pandan Cassava Chocolate Brownies & 000794-07 & \\
\hline Non Gluten & Sweet Potato Steamed Chocolate Muffin & 000794-08 & \\
\hline \multirow[t]{10}{*}{ Muffin } & Sweet Potato Baked Chocolate Muffin & 000794-09 & \\
\hline & Cassava Steamed Chocolate Muffin & 000794-10 & \\
\hline & Cassava Baked Chocolate Muffin & 000794-12 & \\
\hline & Cassava Strawberry Muffin & 000794-13 & \\
\hline & Cassava Strawberry Muffin & 000794-14 & \\
\hline & Sweet Potato Cheese Muffin & 000794-15 & \\
\hline & Cassava Cheese Muffin & 000794-16 & \\
\hline & Cassava Coffee Muffin & 000794-17 & \\
\hline & Cassava Mocha Muffin & 000794-18 & \\
\hline & Sweet Potato Oreo Muffin & 000794-19 & \\
\hline Non Gluten & Sweet Potato Nastar & 000794-20 & \multirow{3}{*}{$\begin{array}{l}\text { PIRT No. } \\
2.06 .1275 .02 .0 \\
202.20\end{array}$} \\
\hline \multirow[t]{8}{*}{ Cookies } & Cassava Nastar & 000794-21 & \\
\hline & Sweet Potato Chocochips & 000794-22 & \\
\hline & Cassava Chocochips & 000794-23 & \multirow{6}{*}{$\begin{array}{l}\text { Halal No. } \\
092000079408 \\
16\end{array}$} \\
\hline & Cassava Cookies & 000794-28 & \\
\hline & Sweet Potato Cookies & 000794-29 & \\
\hline & Cassava Cornflake & 000794-33 & \\
\hline & Sweet Potato Almond Cookies & 000794-34 & \\
\hline & Cassava Orange Cookies & 000794-35 & \\
\hline Non Gluten & Cassava Sticks & 000794-24 & \\
\hline \multirow[t]{3}{*}{ Snack } & Sweet Potato Sticks & $000794-25$ & \\
\hline & Orange Sweet Potato Sticks & 000794-26 & \\
\hline & Cheese Balls & 000794-27 & \\
\hline \multirow[t]{3}{*}{ Eggless Cookies } & Eggless Nastar & 000794-30 & \\
\hline & Eggless Wina Cookies & 000794-32 & \\
\hline & Eggless Kastengel & 000794-36 & \\
\hline $\begin{array}{l}\text { Non Gluten } \\
\text { Cake }\end{array}$ & Cassava Sponge Cake & 000794-31 & $\begin{array}{l}\text { PIRT No. } \\
2.06 .1275 .01 .0\end{array}$ \\
\hline \multirow[t]{3}{*}{ Pattiseri } & Doughnuts & 000794-37 & 202.20 \\
\hline & Risoles & 000794-38 & Halal No. \\
\hline & Pastels & 000794-39 & $\begin{array}{l}092000079408 \\
16\end{array}$ \\
\hline
\end{tabular}

Table 2. Production Capacity and Selling Price

\begin{tabular}{llr}
\hline Product Name & Production Capacity & Selling Price (Rp) \\
\hline Brownies Non Gluten & $100-150$ pcs/month & $30.000,-$ \\
Muffin Non Gluten & $600-800$ pcs/month & $2.500,-$ \\
Cookies Non Gluten* & $5-20 \mathrm{~kg} /$ month & $80.000,-$ \\
\hline
\end{tabular}




\begin{tabular}{llr}
\hline Snack Non Gluten* & \\
Cookies Tanpa Telur* Eggless & $5-10 \mathrm{~kg} /$ month & $80.000,-$ \\
Cake Non Gluten & $5-10 \mathrm{~kg} /$ month & $80.000,-$ \\
Patiseri (Risoles, pastel, doughnut) & $1000-1500$ pcs/month & $30.000,-$ \\
\hline
\end{tabular}

*) The production capacity is high during Eid or New Year

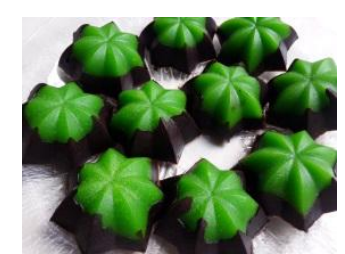

Eggless Cupcake

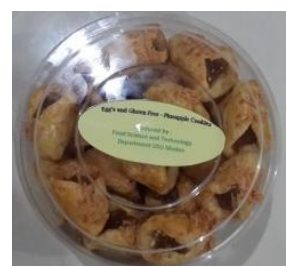

Eggless and gluten-free pineapple cookies

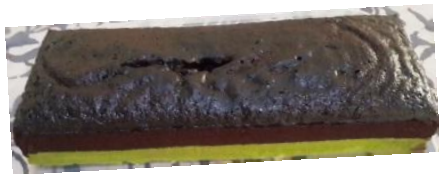

Eggless Cake

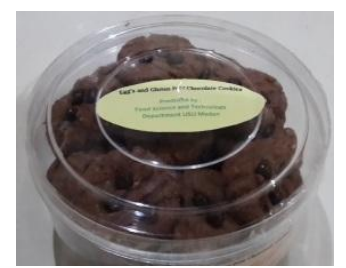

Eggless and gluten-free Chocchips

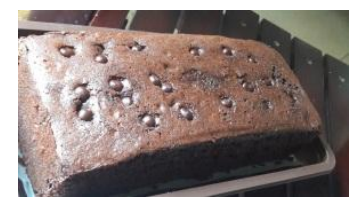

Gluten-free Brownies

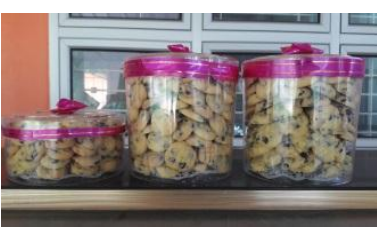

Gluten-free Cookies Cookies Non Gluten

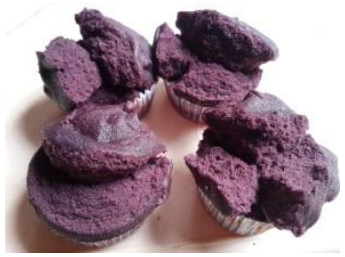

Gluten-free Cupcake

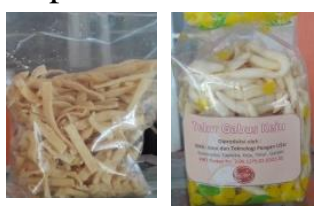

Gluten-free Snack

Figure 1. Eggless and gluten-free cake, brownies, cookies and snacks products

\section{Conclusions}

IbIKK program of low cholesterol and allergen-free bakery products results in the products of cakes and cookies that are low callories and allergen-free which are preferred by the people. Cassava flour, mocaf and sweet potato flour can be utilized as the basic ingredients of bakery products to substitute wheat flour as the support to national program of food security and sovereignty.The use of cassava sweet potato to be flour and bakery products can increase the commodity value of cassava and sweet potato which on its turn it will serve to increase the earnings of the local farmers.

\section{Acknowledgment}

We would like to show our gratitude to the Directory of Research and Community Service of the Ministry of Research, Technology and Higher Education that has funded the community service program through Knowledge and Technology scheme for Campus Creativity Innovation in 2015 - 2017. 


\section{References}

[1] Bisnis.com. 2017

[2] Wieser, H., dan Koehler, P. 2008. The biochemical basis of celiatic disease. Cereal Chemistry, 85: 1-13.

[3] IITA.1985.

http://industri.bisnis.com/read/20150213/12/402601/franciscus-welirang-\%09pertumbuhan -impor-gandum-menakutkan (Accessed on 17 November 2017). IITA research brief 6(3):8

[4] Okaka, J.C. 1997. Cereals and legumes: Storage and Processing Technology. Data and Microsystem Publishers, Enugu, Nigeria pp11-124.

[5] Okafor, J.N., Ozumba, and A.U., Solomon, H.M. 2002. Production and acceptability of chinchin fortified with Oyster mushroom. Nigeria Food Journal18 :9-20

[6] Singh, S., Riar, C.S., and Saxena,D.C. 2008. Effect of incorporation sweet potato flour to wheat flour on the quality characteristics of cookies. African Journal of Food Science 2 : 065-072. 